\title{
Nikolai Berdyaev's Creative Ethics of Personality and Christian Worldview
}

\author{
Anton C. Sevilla
}

\section{ABSTRACT}

How are we to respond to a world troubled by sudden and deep global changes and tormented by enslaving pressures from every corner? This essay responds to this question by exploring the ethical thought of Nikolai Berdyaev. Particularly, this essay describes the main features of creative ethics and the notion of personality that forms the foundation of this ethics. This essay also discusses the Christian worldview that nourishes and is nourished by creative ethics through an analysis of the particularities of Berdyaev's appropriation of four key Christian concepts: goodness, God, eternity, and paradise.

KEYWORDS: Berdyaev, Creative Ethics, Metaethics, Christianity

\section{Introduction}

The present age is a morally chaotic one. With the widening of the globalized world, we have become exposed to different material lifestyles, sciences, religions, and cultures that all offer different (and often incompatible) ways of understanding the world and deciding one's life. The responses to this chaos are equally manifold. Fundamentalism in all its forms is on the rise; some religions, states, and cultures choose to close their doors to the plurality surrounding them. Others preach a relativistic and wholesale tolerance of and non-interference with other ways of life.

Looking at this moral landscape, on the one hand, we are challenged to acknowledge the unprecedented change and pluralization of moral pathways around us. But on the other hand, we are also challenged to arrive at a moral 
clarity that will allow us to participate in the transformation and self-direction of the globalized world. In response to these, we turn to the teachings of Nikolai Alexandrovich Berdyaev (Николай Александрович Бердяев 1874-1948)not in order to find doctrinal refuge from these challenges we face, but to find the wisdom that will let us discover our own spiritual strength to face these challenges courageously.

A brief note on the related literature: Most of the literature in English on Berdyaev was written in the 40s, 50s, and 60s. There are, unfortunately, only a few publications on Berdyaev that were written from the 80 s onward. Furthermore, most of the literature focus on comparative studies of Berdyaev (Hartshorne), or expositions of various Russian, religious (Richards, Erlandson), existential (Hazelton), or political (Garner and Richards) ideas present in Berdyaev's thought. This essay hopes to revive interest in Berdyaev's thought, focusing mostly on his ethical importance in an international, post-modern milieu.

This essay, through a structured and in-depth reading of key passages from Berdyaev's books, wishes to give a concise introduction to Berdyaev as an ethical thinker. It begins with a definition and exploration of Berdyaev's fundamental idea of creative ethics and its relation to two other types of ethics-the ethics of law and the ethics of redemption. Then, it explores the foundation of creative ethics, which is the idea of personality. Having thus solidified the main structures surrounding Berdyaev's creative ethics, it will briefly survey the Christian conceptions that are transformed by and give support to Berdyaev's ethical thought. It will describe four concepts: goodness, God, eternity, and paradise, explaining Berdyaev's position objectively, in hopes that more educated readers might situate it amidst the intricacies of Christian philosophy and apologetics. With this, it wishes to fully articulate Berdyaev's ethical response to the challenges of moral chaos from the ground of his unique Christian experience.

\section{Berdyaev's Creative Ethics}

Nikolai Berdyaev was a controversial man. According to a biography by Dimitri Lisin, Berdyaev was born in 1874 to an aristocratic family in Kiev. Since childhood, he displayed a remarkable sense of autonomy. Surrounded by literary and philosophical classics, he was learned even in his early years. 
Breaking off from a family tradition of serving in the military, Berdyaev decided to enter university and pursue the life of a scholar. But he was no quiet intellectual-in 1898 he was arrested for participating in anti-government Marxist student demonstrations, and when his involvement in other underground activities was discovered, he was expelled from university and exiled to central Russia. He spent most of his exile surrounded by freethinking intellectuals and bore no remorse for his actions. Around 1917 Berdyaev ran afoul with religious authorities because of an article critical of the Holy Synod of the Russian Church. This time, he was found guilty of blasphemy and was exiled to Siberia. Fortunately, the communist revolution prevented his exile from being carried out. However in 1921, Berdyaev's ideological hostility towards the communist regime led to his arrest under the charge of treason. The next year, he was ordered to leave Russia or risked being executed. He moved to Germany and France, and found himself as an outsider in many Russian circles because of his antipathy to both communism and the old ways of life that preceded it. Looking at Lisin's biography of the philosopher, it would seem that he was from birth a rebel par excellence.

Similar to our fate in this contemporary globalized world, Berdyaev too lived a life surrounded by enslaving regimes and ideologies that have gained influence throughout revolutionary Russia. But Berdyaev's response was not to build a political, cultural, intellectual, or spiritual barricade to keep the forces of chaos and change at bay. Instead, his response was to open himself up to the possibilities offered by chaos and change, and to find a way to face them courageously. This response congealed and found form in what he refers to as an ethics of creativeness-creative ethics.

The notions of creativity and creative freedom are present in all of the works of Nikolai Berdyaev, from The Meaning of the Creative Act in 1916 to Truth and Revelation around 1950. But the notion of creativity as an ethical idea is clearly and coherently developed in his book The Destiny of Man. In this book, Berdyaev (126) grounds the spiritual legitimacy of creative ethics on The Parable of the Talents (Matthew 25:14-30). In this parable, we see that it is not only those who waste the talents given to them, but even those who merely safeguard these talents get cast out. Who are able to truly fulfill the task given by the master? It is only they who are able to take a chance with their talents and multiply these talents fruitfully who are truly doing their master's will. Berdyaev interprets this to mean that in this changing world, it is not suffi- 
cient for us merely to safeguard our moral resources by the light of what has been determined to be the right path. Instead, it is necessary for us to venture forth into the darkness of the chaos of the world and create new values, new forms of goodness, new ways for the light to shine upon the winding terrain of this changing world.

Berdyaev's idea of creative ethics is formed as a response to what he considers to be a widespread and legitimized form of moral bankruptcy, namely the ethics of law. Ethics of law is understood as all forms of ethics that take the idea of the good to be higher than the moral actor himself. By taking the idea of the good as their basis, these forms of ethics become normative and legalistic (Destiny 105). When the idea of the good is taken as fundamental, those who act against this idea are persecuted for being evil. While those who act in accordance with this idea are accepted, not for their own goodness but for their capacity to uphold the idea of the good. In other words, for Berdyaev, the ethics of law makes goodness a measure of personhood. Instead of seeing persons, we merely see the goodness or the evilness by which a pharisee or a prostitute is measured. Since ethics of law is moral objectification, it has lost sight of what is the center of ethical life, the human personality as made in the image and likeness of God.

In response to the ethics of law, Berdyaev raises the need for an "ethics of redemption." Berdyaev considers the coming of Jesus Christ as a historical manifestation of an ethics of redemption. From birth in a manger to a ministry amongst the sinners that rebuked the morally righteous, all the way until his death on a cross-betrayed by a disciple and championed by a thief-Jesus's life can be understood as a revolt against all that is expected of the messiah, a revolt against the moral orders of society. Jesus came as a fire that burned away our moral objectifications of what was good and what was evil, what was lofty and what was base.

Berdyaev understands this as an overturning of the ethics of law. While the ethics of law condemns evil and shuns the impure and sinners, ethics of redemption understands that wickedness is an inseparable part of the human struggle. An evil situation may become the opportunity for a deep response of human goodness, just as goodness can become a source of pride and deep moral evil. This inseparability means that evil cannot merely be condemned and goodness alone can be saved. If only the good in a person were saved, a large and integral part of his personhood-his desires, dark parts of his past 
that have formed him-would remain in hell. Hence for the ethics of redemption, what matters is not goodness nor the salvation of good men, but the salvation of all people, in their entirety, as good and evil. It is only through this acceptance of the evil and morally absurd within human life, mediated by the ethics of redemption, that we are able to return to the true ground of ethics which is not merely an abstract idea of good, but truly the concrete reality of human personality.

On the ground of personality unconcealed by the ethics of redemption, an "ethics of creativeness" becomes possible. For Berdyaev, creative ethics is the third and highest form of ethics. One's action is no longer founded on a heteronomous idea of goodness that measures man from without; nor is one constrained by the sclerotic ways of the herd man, having to do as "one ought to do." In creative ethics, "One ought always to act individually and solve every moral problem for oneself, showing creativeness in one's moral activity, and not for a single moment become a moral automaton" (Destiny 132). Creative ethics frees the individual to act as himself. As one breaks beyond the lines drawn by the collective and learns to see for oneself, one discovers that in the uniqueness of one's experience of moral reality, it becomes possible to find opportunities for goodness that are unseen to others and that he may find ways to be good in ways heretofore unthought of. In doing so, ethics becomes one's own-a creative and unique manifestation of one's personality and unique struggle for goodness.

However, this is not to say that the preoccupation of creative ethics is with the self. While creative ethics must come from the self and its own individual experience of moral reality, its concern is no longer the self or its salvation. Berdyaev writes:

Creative genius is bestowed on man for nothing and is not connected with his moral or religious efforts to attain perfection and become a new creature. It stands as it were outside the ethics of law and the ethics of redemption and presupposes a different kind of morality... . Creative genius is not concerned with salvation or perdition. In his creative work the artist forgets about himself, about his own personality, and renounces himself. Creative work is intensely personal and at the same time it means forgetfulness of self. (Destiny 130). 
This self-renunciation is a turning toward other personalities. For Berdyaev every person in its individuality is seen as the highest moral value, as the end that is respected by each moral act (Destiny 134). One might say that we must not only act from our own persons, but we must also let others act from their own persons. We are called to participate in each individual's struggle with their own moral objectifications, with their slavery to the idea of the good. We are called to help people see themselves as persons even when they themselves can see nothing but their goodness or their evilness. Furthermore, we are called to help people gain the courage to create their own values from their own direct apprehension of themselves and their moral realities.

Berdyaev's response to the socio-political revolution surrounding him and the pressures seeking to constrain and enslave him was one of courage tempered by openness. This was made manifest in his notion of creative ethics, an ethics that did not surrender the uniqueness of the individual and the freedom of one's own moral experience for the measuring stick levied by the pressures of the herd. The standpoint of his notion of ethics is the ground of personality and at the same time, fidelity to personality commands nothing short of a creation of new values in response to one's own moral reality. However, such a form of ethics raises critical questions: what is this personality that forms the basis and directive of creative ethics? What does it mean to create values, and what does this spell for one's understanding of goodness and God? In an ethics of personality for personality, what sort of paradise awaits, what sort of eternity is in store?

\section{Personality}

The disparate strands of thought that form the unsystematized tapestry of Berdyaev's work serve to protect and uphold courageously what he calls the personality. While creativity and freedom form the more visible components of his work, creative ethics is only ethical in so far as it emanates from personality and values personality. Creative ethics and the freedom equal the practice of personality.

So how might one begin to understand Berdyaev's notion of personality? As the central idea of an unsystematic body of thought, the idea of personality is a complex amalgam of aspects, many of which are in tension with each 
other. There are three main facets highlighted here: first, personality as particularity, second, personality as spirituality, and third, personality as a task for self-transcendence.

\section{This Personality}

Personality, first and foremost, is the actual and concrete reality of the human existent taken as a whole-in-itself. With this notion, Berdyaev attempts to do two things at once: first, he wishes to draw us away from all the partial notions, which have been generalized and abstracted of the human reality, toward the entirety of the human person. Second, he wishes to draw us away from the tendency to subsume the individual to a greater whole, toward the tendency to acknowledge the unique and unrepeatable reality of the person as a whole unto himself.

Berdyaev (Destiny 48-49) raises his opposition to various views of the human person, which includes criticizing the biological view of the human being as homo sapiens, the Greek and enlightenment view of the human being as a rational animal, and the modern European view of man as "a product of society and also as an inventor of tools (homo faber)" (Destiny 49). For Berdyaev, these views of the human person take only parts of the totality of his personalityhis biological constitution, his autonomous reason, or his function in society. In so doing, an ethics founded upon these views of the human person offers a limited response to the human person, neglecting facets unfounded within its views of the human person.

Moreover, by taking only facets of the totality of personality and abstracting them, it becomes possible to subsume the individual as a member of a group. The human being as homo sapiens is just a member of a species. As animale rationale he is one autonomous bearer of the law amongst others. As homo faber he is only a member of society's cog in the wheel of its needs production. Hence, if one abstracts from the plurality of facets of personality and does not take the personality as a whole, then, there lies the danger that the human being will be subsumed and tyrannized by a larger collective and that it becomes a functionary to, instead of being taken as a whole unto itself.

Berdyaev takes a different approach to the personality. For him, if we are thinking about an individual in so far as he bears traits that can be attributed 
of others, we have yet to arrive at the personality. If we only think about a homo sapiens, or a rational man, all of these things are parts of a greater whole. But the personality, seen in its wholeness is never part of a whole, not even of the whole of the universe or of the whole of history (Slavery 20-26).

Instead, personality is the whole concrete reality, every material and temporal facet of it, its life story and its material constitution, yet as a wholein-itself irreplaceable and irreducible to a part of a whole. Berdyaev writes, "Personality is my whole thinking, my whole willing, my whole feeling, my whole creative activity" (Slavery 25). That is not to say that personality is a body or a thinking thing, or a feeling thing, or a will-for all these are merely categories attributable to other things. Personality is not a genus or a category. Instead, personality is always this personality, here and now. As such, Berdyaev (Slavery 23) sees the existence of each personality as something absolutely irreplaceable and unique. When we stand before the concrete and actual personality before us, not in reference to any other whole but as a whole in itself, the dimension of personality and the realm from which it breaks forth becomes manifest to us.

\section{The Spiritual Dimension}

As a concrete, irreplaceable, and unrepeatable unique whole, personality manifests a rupture. Berdyaev writes: "Personality is a break through, a breaking in upon this world; it is the introduction of something new" (Slavery 21). This breakthrough beyond the whole, the objectified world, and the generalization of the parts of universe and history presents a different dimension, the dimension of the spirit. In The Destiny of Man, Berdyaev writes:

The individual is produced by the biological generic process; it is born and it dies. But personality is not generated, it is created by God. It is God's idea, God's conception, which springs up in eternity... . Personality is the image and likeness of God in man and this is why it rises above the natural life. (55)

As a Christian, Berdyaev understood the rupture manifested by the concrete personality as a testament that we were made in the image and likeness of God. The mark of the divine in us is not found within us, nor is it merely one part of us. Instead, the mark of divinity itself is the irreplaceable organic whole 
of our physical, spatio-temporal constitution, our entire selfhood in all of its facets, as it unfolds in our own personal histories. It is the breakthrough of the realm of the spirit.

But what does Berdyaev mean when he refers to the realm of the spirit? Is he referring to a different order of reality, altogether different from the world of meanings and objectifications that we find ourselves in? On the contrary, Berdyaev (Existentialism 36) considers the spiritual world not as an objective reality apart from this one, but as this world in itself, seen in a wholly different light. Berdyaev continues, "Spirit gives meaning to actuality, rather than being itself, another actuality. Spirit is, as it were, the breath of God penetrating man's being and communicating a higher dignity, a higher quality of his existence, inner independence and unity" (Existentialism 36-37). If the objective world can be described as a cold world, with its set values of power and market forces, if it is filled with hardened visions of who people are and how they can live out themselves, constrained by the constant voice of the herd, the they [Das Man] that says "one does..., one does not...," then the spirit is a warm breath that melts the ice of fear-driven objectification, that tells of a world that is filled with passionate possibilities. "The spirit is freedom" (Existentialism 37).

The freedom of spirit is manifest in the character of spiritual and unobjectified knowledge. Berdyaev writes:

Knowledge does not consist in man's passively receiving into himself the objects of knowledge-ideal, non-human entities (Wesenheiten); it implies man's spiritual creative activity. The meaning of things is revealed not through their entering into man who is passive in relation to them, but through man's creative activity reaching out to meaning beyond an unmeaning world (Destiny 8).

The spiritual dimension means seeing the world through the eyes of freedom. In actively finding new ways to see things, new ways to pull reality together and give it meaning, we transform the world and make it shine in a light that is truly our own. But does this mean that spiritual knowledge and the spiritual dimension are purely subjective? While Berdyaev often says that spirit and personality are subjective, it does not mean that they are disconnected from 
actual realities. Spiritual knowledge is not in the subject separate from the objective world or in the objective world separate from the subject, but in the dynamic, continuous and mutually transformative relationship between subject and object, between knower and known (Destiny 8-9). Hence, with each coming forth of personality, the image and likeness of God, we have the opening up of a world of creative possibilities; we re-imagine and rediscover reality in the intimate relation between self and world that is spirit.

\title{
The Task of Personality
}

We have spoken of personality, the image and likeness of God, in terms of being our concrete actuality seen as a whole in itself and the breaking forth of the spiritual dimension, of possibility and creativity, into the world of objective reality. All the while, we have spoken of personality as what we are. However, while personality is something that we already are, personality is equi-primordially that which we are called to become. Berdyaev writes:

\begin{abstract}
Personality is self-constructive, not a single man can say of himself that he is completely a person. Personality is an axiological category, a category of value. Here we meet the fundamental paradox in the existence of personality. Personality must construct itself, enrich itself, fill itself with universal content, achieve unity in wholeness in the whole extent of its life. But for this, it must already exist. (Slavery 23)
\end{abstract}

We are all unique-we are born unique and have lives that are individual and distinct from others. But do we live out this unique individual that we are? Or do we sacrifice our uniqueness to conform to the pressures of society? Despite the irreplaceable individuality of the journey of one's life, one cannot but admit that so many people have abdicated their own journey to run a race that is not even their own. We are all loci of the breaking-forth of the spirit. But do we live spiritual lives? How many ideas have been born and reborn in our minds, only to gather dust as we cling to the objectifications of the fearful herd? We are personality, but to become personality requires clarity to see oneself and courage to be oneself. This courage is an ethical task.

In addition, our uniqueness and spirituality form a tension. In our uniqueness, we are our own persons: we possess our own particular bodies and spe- 
cific histories. But uniqueness and courageousness in being faithful to one's personality are not sufficient to be the spiritual beings that we are called to be. As spiritual beings, we belong not to ourselves but to a space of encounter, of meeting and mediating the other, in order to become meaningful in ways only we can undertake. We exist as ourselves and fidelity to ourselves is our task. At the same time, however, are we capable of generously giving of ourselves in opening up to reality?

Berdyaev writes: "Man is a being who surmounts and transcends himself. The realization of personality in man is this continuous transcending of self" (Slavery 29). The creativity, which is our birthright, is possible only if in being faithful to ourselves in our individuality, we unfurl and open the unique space that we are to the other and let that be the space in which the other comes to light and is transfigured. The self cannot be closed unto itself; personality cannot be ego-it must be "a throwing open in love" (Slavery 44).

Learning to open oneself to reality and take part in its self-manifestation and evolution requires courage, as much if not more courage than what is required to learn to see oneself clearly and be faithful to oneself. But to fulfill these two at once, that is to be loyal to oneself and one's path and from the ground of that loyalty to open oneself selflessly and lovingly-this is what it truly means to be personality. This personality that we are is an ethical task par excellence.

\section{Creative Ethics as a Practice of Personality}

Creative ethics is a practice of personality. It begins with personality and proceeds toward personality. Every political and religious battle fought by Berdyaev was in service of personality. In the previous section, we have seen three facets of personality: a) personality as the concrete actuality of the individual seen as a whole unto itself, b) personality as the image and likeness of God and the breakthrough of the spiritual realm, and c) personality as a task for self-fidelity and self-transcendence.

Founding creative ethics in something present in actual reality has profound implications. That personality is not only one part (the "divine part") of a human being means that the entirety of his being taken as a whole unto itself further radicalizes these implications. Any ethics founded on something 
separate from the human person, for instance, on an idea of goodness or an impersonal order, runs the danger of becoming a form of violence, that is, to reject the individual and to see him merely as a means toward an external end. Doing "good acts" toward the other, where schematically, one attempts to take part in another's movement towards the "good," does not necessarily demand an acceptance of the other person; but rather, it may even see the other as a hindrance, an obstacle in the way towards the external good. In such an ethics, each "good act," which schematically can be seen as one's own participation in the "good," will not necessarily be done out of acceptance of one's own reality, but instead may be out of hatred and disgust for one's own immoral nature.

Even an ethics founded on a part of the human person, that is, an ethics that sees that goodness comes from participation in a fraction of man that is good, runs this danger to a certain extent. If ethics is founded, for instance, on universal reason, which is a part, but not exhaustive, of the human person, then it runs the danger that there will only be a partial acceptance of one's own human reality and that of others, and the rest of one's person (for instance the irrational, such as drives and inclinations) may be cast asideignored and trampled by the moral process. Berdyaev's constant criticism of Immanuel Kant's ethics in the Groundwork of the Metaphysics of Morals is a result of this danger.

However, unlike other forms of ethics, Berdyaev's creative ethics emanates from personality toward personality. That means that creative ethics does not issue out of discontentment or rejection of oneself but out of an awareness, respect, and cultivation of what one fundamentally is. Similarly, creative ethics in reaching out to the other does not seek condescendingly to impel the other toward an external good, but instead mindfully and with dynamic acceptance participate in the actualization of the self-integrity of the other.

Oftentimes, acceptance is relegated to "taking someone just the way he is" and leaving him just the way he is. However, such a static acceptance presumes that a human person is a static entity without an element of transcendence within. Berdyaev, however, insists the opposite-the personhood that I fundamentally am is a dynamic process of self-fidelity and self-opening that requires the constant courage for self-transcendence. Hence, can it not be said that my true acceptance of my person ought to also be faithful to this 
dynamic process that I am? True acceptance of one's own reality or the reality of another is a dynamic acceptance that participates in the process of selfdiscovery and sharing of self.

Berdyaev's creative ethics as founded on the notion of personality demands utmost clarity that allows us to be faithful to the actuality of personality before us, to have reverence in accepting it, and the capacity to participate dynamically and whole-heartedly in the self-realization of personality. However, let us not be mistaken that dogma is sufficient to command this of us. Is it really sufficient to take on blind faith that man is made in the image and likeness of God? I have begun with the notion of the concrete actuality of the individual because throughout Berdyaev's life, it has proven to be the foundation for his thought and not some otherworldly affection for divinity.

Personality is first and foremost the concrete and actual individual standing before us in its wholeness. It is your personality, my personality, the personality of those who are most dear to us, the personality of those who we are most unsatisfied with, the personality of those whom we are indifferent to. Can we look at reality and find this personality standing before us? Can we look beyond the objectivization of our world and its impersonal orders, and see this personality as a whole end in itself? From that wholeness, can we see the fissure of the breaking forth of the spirit in its freedom, and the dynamic task of self-transcending self-realization? For it is on this experience, of this vision of personality, that the commitment to and fulfillment of the demands of creative ethics become possible-and not on some abstract ratiocination or blind faith.

\section{Transformations of the Christian Worldview}

Berdyaev's notion of creative ethics is founded on his interpretation of The Parable of the Talents (Matthew 25:14-30), and his understanding of personality comes from his understanding of the the trace of the divine in human beings, and the spiritual dimension from which it comes. Christian ideas, such as The Fall of Man, the redemption through Jesus, the morality of the Pharisee, are woven into the entire tapestry of Berdyaev's thought. It is clear that Berdyaev's philosophy is deeply nourished by Christianity. However, it is also apparent that Berdyaev has his own personal way of appropriating 
Christianity, one that may be different from the mainstream understandings of the Christian faith. In this section, the paper wishes to briefly describe Berdyaev's own understanding of four concepts-goodness, God, eternity, and paradise. The presentation does not intend to convince any Christians of their validity, but only to provide an objective presentation, in the hope that scholars of Christology and interested Christians may be able to situate Berdyaev's thought amidst the spectrum of other beliefs and Christian apologetics.

\section{Goodness}

The first peculiarity one has to deal with in Berdyaev's notion of the good is that it is inseparably tied to evil. Berdyaev writes: 'Good' and 'evil' are correlative and in a sense it may be said that good comes into being at the same time as evil and disappears together with it. This is the fundamental paradox of ethics" (Destiny 35). Good does not have primacy over evil. The state of "pure good," wherein integral personality is not a task to be realized but a consummate fact, is not merely a state where good prevails in its entirety, but rather a state with neither good nor evil. For Berdyaev, good and evil arise together when the integrality of personality becomes a task; that is, good is something ought to be done in realizing the self-fidelity and self-transcendence of personality, and evil is failure to respond to this demand.

For Berdyaev (Destiny 37), the very fact that there is good and evil means that the realization of personality is contingent on action, which indicates the fall and the loss of paradisiacal bliss. He writes, "It is bad that the distinction between good and evil has arisen, but it is good to make the distinction, once it has arisen; it is bad to have gone through the experience of evil, but it is good to know good and evil as a result of that experience" (Destiny 37-38). In a world where personality requires realization, there is a need for ethics and for a distinction between good and evil. The distinction between good and evil must be proper, and the appropriateness of this distinction develops in the three forms of ethics Berdyaev discusses: the ethics of law, the ethics of redemption, and the ethics of creativeness.

Berdyaev's criticism of the ethics of law has been discussed earlier. Such a criticism, however, does not mean that Berdyaev sees no value in an ethics that normatively dictates what all people should do. While it tends to ignore the inner life of personality, the law does protect the person from violence, even in situations that are not ruled by higher forms of morality (Destiny 101). 
Good and evil in ethics of law are not so much about realizing personality but about protecting persons within society.

The social locus indicates the nature of this ethics as well. "The ethics of law is the expression of herd morality. It organizes the life of the average man, of the human herd, and leaves altogether out of account the creative human personality which rises above the common level" (Destiny 91). It comes from the collective and represents common interests and shared survival of the community.

This organizing force that allows for human survival in society is important, but for certain it also carries dangers. While the law creates order, it also causes stagnation and prevents the active creation of new forms of order in response to novel situations (Destiny 90). Berdyaev writes:

The fatal consequence of the legalistic discrimination between good and evil is tyranny of the law which means tyranny of society over the person and of the universally binding idea over the personal, the particular, unique and individual. The hard-set crystallized forms of herd life in which the creative fire is almost extinct oppress like a nightmare the creative life of personality. (Destiny 92)

For this reason, Berdyaev asks to break the normative idea of goodness, not by way of cancelling it, but by way of transcending it positively (Destiny 95). For Berdyaev, the higher force that overcomes the ethics of law through the ethics of redemption is none other than Jesus Christ himself.

The ethics of redemption is best illustrated when Berdyaev quotes Scripture: "I am come to send fire on the earth" (Luke 12:49). In this fire are burnt up all the old, habitual moral valuations, and new ones are formed. The first shall be last, and the last first" (Destiny 109). Jesus Christ overturned all of the Judaistic norms of goodness. From the circumstances of His birth, to the betrayal by an apostle, to the conversion of a thief who belonged to a band of murderers, all the way to the manner of His death, everything about and surrounding Jesus Christ was radically different from what was expected of the messiah. By spending time with Samaritans, tax collectors, and prostitutes, by criticizing the morally righteous Pharisees, by putting the first last and the last first, Jesus heralded a revolutionary order of goodness. 
Berdyaev interprets Christianity and its ethics in the following manner:

Christianity in its original and virginal form not merely questioned the supremacy of the idea of the good, but sharply opposed its own morality based on it. Christianity is founded not upon the abstract and impotent idea of the good which, in relation to man, inevitably appears as a norm and a law, but upon a living Being, a Personality, and man's personal relation to God and to his neighbours. Christianity has placed man above the idea of the good and thereby made the greatest revolution in history-a revolution which the Christians had not the strength to accept in its fullness. (Destiny 105).

By overturning the norm of good and evil, finding good in the depth of every sinner, and self-righteous evil in the heart of those who were righteous, Jesus Christ moved beyond the dualism of good and evil and reached into the forgotten depths of moral reality, the depths of personality prior to the superficializing reign of normative goodness. He reached beyond all moral objectification into the inner moral experience of each human being, in order for the notions of good and evil to find their true basis once again.

Creative ethics moves beyond the normative good and evil of the ethics of law, and beyond the neither-good-nor-evil of the ethics of redemption. From the ground of personality and inner moral experience opened up by Christianity, the distinction between good and evil can arise from their proper ground. From the actual reality of personality and the actual frontiers that personality faces for itself and other personalities, one can authentically discern good and evil, free from the constraint of the impositions of the herd.

With this freedom, ethical discernment becomes creative. It creates values that are not necessarily dictated by any form of authority. It finds new ways to enact old goods, and discovers completely radical paths to goodness in the face of the changes of our moral landscape.

This creativity indicates a change in approach: creative ethics is no longer fixated with waging war on sin and evil, but instead devotes its energy to the free creation of goodness (Destiny 133). By championing the present existence of the human being, it frees the human being from fear of the future and death, imbuing the person with a deep sense of moral courage (Destiny 135-36). 
Creative ethics indicates a fidelity to and an affirmation of one's existence; it likewise points to the accompanying task. It breaks from the perpetual fixation with death and sin, and rests in the timeless value of personality and the goodness that radiates from it. It is, however, when we are able to return to the true foundation of good and evil-personality and its realization-that the tragedy of good and evil appears to be overcome. Creativeness brings us back to the paradise before the fall, to a genuine experience of existing beyond good and evil (Destiny 131).

It appears we have strayed beyond the question of goodness to more questions, on God in relation to this creative goodness, and on time and eternity and the question of paradise. We discuss them in the following sections.

\section{God}

It is extraordinary how limited is the human conception of God. Men are afraid to ascribe to Him inner conflict and tragedy characteristic of all life, the longing for His "other," for the birth of man, but have no hesitation in ascribing to Him anger, jealousy, vengeance and other affective states which, in man, are regarded as reprehensible. There is a profound gulf between the idea of perfection in man and in God. Self-satisfaction, self-sufficiency, stony immobility, pride, the demand for continual submissions are qualities which the Christian religion considers vicious and sinful, though it calmly ascribes them to God. (Destiny 28)

Berdyaev was deeply troubled by what he viewed as misunderstandings of God that arose from the attempt of objectivization to arrive at the spiritual reality of God, and he waged a relentless war against the despotic idea of God. In this section, we shall explore Berdyaev's view on the misunderstandings that arise from a rational objectification of God as absolute. It is best to see Berdyaev's views within the spectrum of Christian apologetics (for instance, Norman Geisler's Christian Apologetics presents a critical view, whereas Douglas K. Erlandson's "Timelessness, Immutability, and Eschatology" supports Berdyaev's ideas), but unfortunately that is beyond the scope of this paper. Let it suffice to note that these views on God are presented not as theological arguments but as manifestations of the particularities of Berdyaev's religious views in so far as they coincide with and support his notion of creative ethics. 
For Berdyaev, narrow rational objectification of God leads to an idea of God as absolute, pure act, self-sufficient, and purely independent of His creation. He writes:

The conception of the Absolute is the extreme limit of the objectivizing of abstract thought. In the Absolute there are no signs whatever of existence, no signs of life. The Absolute belongs not so much to religious revelation as to religious philosophy and theology. It is a product of thought... . You cannot pray to the Absolute. No dramatic meeting with it is possible. (Slavery 84)

For Berdyaev, misunderstanding God as absolute makes Him distant and cold, one that denies our relationship with Him. But more dangerously, this misunderstanding renders our relationship with God and our very existence meaningless. Berdyaev laments, "The theologians know very well, although no one knows where they got this knowledge, that God's creative act has no significance within the inner Divine life, that it reveals no movement in Divine life, no sort of enrichment" (Existentialism 48). If God were absolute, a static perfection that lacked nothing and required nothing, then why did He create? Would there be no meaning, no need that His creation fulfilled?

Moreover, this creation is rank with evil and suffering. In reading the works of Elie Wiesel, one cannot but shrink from the sheer horror of the evil that human beings suffer, only to be drawn to it and perpetrate it themselves. Evil is older than the Holocaust, and has greatly outlived it. Every new era bears a new evil that makes us suffer. But why would God create such a world as this? Berdyaev (Destiny 24) condemns the idea that fate weeds the weaker souls that are destined for Hell from those that give glory to God and are destined for Heaven. One might say that the idea of a God who created people to endure the trials of Hell on earth so they might give glory to Him would be an idea of a cruel and evil God.

Of course, the existence of evil is often ascribed to the creature's abuse of his God-given freedom (Destiny 23). But this hardly explains the problem of evil. Berdyaev writes, "The freedom through which the creature succumbs to evil has been given to it by God, i.e. in the last resort is determined by God. Freedom is a fatal gift which dooms man to perdition." Elsewhere, Berdyaev (Destiny 284) writes that the 'gift' of freedom has created Heaven and Hell, 
where once there was only Paradise-Hell appears to be the only thing won by freedom. What sort of a God gives such a frightful gift, and for the sake of nothing, since God neither lacks nor requires anything?

For Berdyaev, all this arises from the misunderstanding that God is absolute, that He is the creator of everything-creature, personality, freedomyet, being absolute, he is completely independent of this creation. Berdyaev, therefore, cannot see God as an absolute. For Berdyaev (Existentialism 48), we need to have a notion of uncreated freedom, that is a freedom that does not come from God, in order to escape the view that God is merely toying with his creation in history. If creation were to mean anything, if there were to be anything gained from the relentless struggle with suffering, if there were to be any sense in the sending of Jesus Christ to save this creation, then creation must be intimately tied to the inner dynamic of God Himself:

The creation of the world is creative development in God. (Existentialism 49) [emphasis supplied]

In this respect, Berdyaev is very much akin to the process philosophy of Alfred North Whitehead. Charles Hartshorne himself writes, "Both [Berdyaev and Whitehead] view as supreme mistakes the denial of 'movement' (Berdyaev), of 'flux' (Whitehead), to the divine consciousness; and both oppose the assertion of God's sheer absoluteness, self-sufficiency, or inability to derive increase of value from the creatures" (72). One of the most enigmatic phrases in Berdyaev's thought is this:

Esoteric theology is bound to recognize the presence of tragic conflict in God. It is what Jacob Boehme calls the theogonic process. It takes place in eternity and signifies not the birth of a previously non-existent God, but a divine mystery-play going on in the eternal hidden life of the Deity, the perpetual birth of God out of the Ungrund. (Destiny 29)

For Berdyaev, God is not absolute. Instead, "God is relative to creation, to the world and to man, and with Him takes place the drama of freedom and love" (Slavery 85). God is not immobile, instead He is Spirit and Freedom, constantly born out of the nothing, creating Himself and finding Himself in 
each situation, through the existence of every personality. God did not create the freedom that dooms us to a life of sin; instead, God is freedom and is born into an Ungrund that is not-yet God. As Freedom that has given freedom of itself, God struggles with us and through us in a theogonic process that may allude to a growing self-fidelity of God to Himself.

In a sentiment that has often been considered heretical, Berdyaev asserts: God needs us. God created us because he longs for us. God sent us His only Son because our fate matters deeply to Him. Berdyaev writes, "There are two movements, and not one: from God toward man, and from man toward God... . The birth of man in God, man's answer to God, cannot concern God alone; it is man's affair, a matter of man's freedom.... The Kingdom of God cannot be realized without man" (Existentialism 43).

It becomes clear here how the line, "we are made in the image and likeness of God," is one of deep ethical importance. It means that like Him, human beings are free. Like Him, we can create-not just mere things, but goodness and values that allow goodness to shine in the darkness of new and godless circumstances. Even more than that, our freedom and our task toward creative ethics are fundamentally tied to the fate of the Divine itself, and that means our responsibility is infinite. Infinitely burdensome, but also, infinitely meaningful.

\section{Eternity and Paradise}

Infinitely meaningful-this last line brings us to ultimate things. Ultimate, that is, the end of time and the coming of the Kingdom of God, eternity, and paradise. But when is the end of time? For Berdyaev, the answer is not to look forward, but to look underfoot, beneath the veneer of objectified time.

For Berdyaev, the idea of eternity arises in opposition to time and the objectivizing slavery that we suffer from it. But how does he understand objectivized time? In Slavery and Freedom, he describes three kinds of time. The first two are objectified forms of time: cosmic time and historical time. The third brings us toward eternity-unobjectified existential time.

Cosmic time for Berdyaev (Slavery 257-258) is symbolized by a circle that represents the revolution of the earth around the sun (years), the revolution of the moon around the earth (months), the rotation of the Earth (days), and so 
on. Cosmic time is the time of impersonal repetitions-the tides, the seasons, the waxing and waning of the moon. Berdyaev says, "Cosmic time is objectivized time, and it is subject to mathematical calculation" (Slavery 258).

Perhaps this objectification of time is tied to man's struggle for survival amidst the impersonal rhythms of nature. Night and day dictate the coming and the going of predators of the animal kingdom and dangers that humans have faced from the beginning. For this author, due to this Darwinian urgency to survive, the first concepts of time to be formed must have been "night" and "day"; these concepts have shaped the rhythm of human life ever since. The coming and going of the seasons dictate man's farming habits and his needs for food and shelter, and because of this, it is necessary that these changes be understood, and that understanding be captured in concepts-winter, spring, summer, fall, years, months, and so on.

This primitive understanding of time as keeping pace with the changes of nature in a race for survival is perfectly mirrored in contemporary manthe annual rhythms of work, the monthly wait for one's paycheck, the weekly rhythm of trudge and toil while yearning for rest, the organizer broken down to the last hour, which structures one's day in accordance to the cyclic demands of making a living. When we think of keeping pace with impersonal time that waits for no one-not the tired nor the infirmd-for certain we have a sense of what Berdyaev (Slavery 258) means when he refers to time as a disease, a mortal disease that eventually catches up with the individual in death.

Berdyaev then discusses historical time, which is more personal than cosmic time, perhaps even arising in rebellion against cosmic time (Slavery 259-60). He characterizes historical linear time as a reaching forward and striving for progress toward a future and reaching back and longing nostalgically for golden ages past. In this reaching both for the future and past, man constantly attempts to secure himself amidst the impermanence of cosmic time. Each moment of this self-securing is measured in terms of progress and restoration.

However, historical time is marked by suffering and dangerously oppressive. He writes, "Historical time is time which is torn to pieces. It does not find completeness in any kind of present. In the present man does not feel the fullness of time, and he seeks it in the past or in the future, especially in 
periods of history which are transitional and full of suffering" (Slavery 260). More than the restless anxiety of historical time is the peril of enslavement to it (Slavery 255). In the incessant drive either towards progress by building a utopia in the future or towards restoration by bringing back a lost golden age, the person can lose all personality and become totally subjugated to the movements of history. People can be "sacrificed for a better tomorrow," oppressed for "a brighter future for our children." Berdyaev criticizes Hegel bitterly for this, "[Man] is crushed by history and consents to be a tool for the accomplishment of history, to be made use of by the artfulness of reason (Hegel's List der Vernünft.)" (Slavery 255).

While Berdyaev raises historical time primarily as 'herd time,' it is not to say such is no longer a problem in the individualistic age. Whether or not we are aware of a sense of history (of the heritage of our country and its golden years), whether or not we long for a sort of utopia in the future, we remain anxiously tethered to the past and the future in our own personal histories, where glories of the past (real or imagined) or promises and demands of the future tug at the present and put it to measure. Whether as individual or as part of a community, historical time deprives the moment of personality of any real satisfaction or completeness.

And yet despite being embroiled in the struggle of historical time and hurrying to keep pace with cosmic time, there is a third form of time, a time that is not time-existential time. Existential time is described as a point (Slavery 260), neither tethered to the past or the future like the line of history nor tumbling about within the wheels of cosmic time. Berdyaev describes it as such:

The present in which there is fullness and perfection is not a part of time, but an emergence from time, not an atom of time, but an atom of eternity, as Kierkegaard says. That which is experienced in the depth of this existential moment remains. The successive moments which enter into the sequence of time and represent a less profound reality, pass away. (Slavery 260)

In existential time, the present moment is taken as a whole in itself. Unlike a moment of historical time the present is no longer subject to the self-fragmenting onward rush for the future or to the nostalgic longing for the past. Since it exists in fidelity to itself, it has no need to endure or fight for its existence in the roil and toil of cosmic time. 
Each moment of existential time, therefore, is a rupture of cosmic time and historical time, and through this rupture, a new order breaks into the flow of time and history. As a moment free from the demands of time and the compulsions of history, Berdyaev describes this depth of freedom as a vertical depth, anti-parallel to the horizontal flow of time: "Everything which is accomplished in existential time, is accomplished along a vertical line, not a horizontal. In terms of the horizontal line it is only a point, at which the break-through takes place out of the depth onto the surface" (Slavery 261).

In this depth of freedom, the moment of existential time is infinite-that is, not a quantitative infinity, but a qualitative one. This infinity is a manifestation of eternity itself. Eternity is not something purely outside of (cosmic and historical) time. In The Meaning of History, Berdyaev (64-66) states how time and eternity are not mutually exclusive, and that time is within eternity; this way, a moment can break past into eternity and reveal something timeless.

But how might we arrive at this timeless atom of eternity? Berdyaev writes, "Man is free when he finds himself in a state of creative activity. Creativeness leads to the ecstasy of the moment. The products of creativeness are within time, but the creative act lies outside time" (Slavery 253). Creative ethics is not concerned with protecting the personality from violence and destruction; nor is it primarily concerned with the redemption of personality and its value. Instead, creative ethics stands on the ground of this personality at this present moment, in fidelity to the uniqueness of its moral experience, realizes itself as the personality that it is.

Berdyaev writes, "Victory not only over the fear of death but over death itself is the realization of personality. The realization of personality is impossible in the finite, it presupposes the infinite, not quantitative infinity but qualitative, i.e. eternity" (Slavery 252). In the preceding discussion we have seen that this does not mean that in order for personality to come to its realization, we have to transcend finite time into eternity. Rather, the converse is true: in realizing personality, that is, being faithful to ourselves as personality for personality, we transcend the demands and compulsions of time and history and enter into the qualitative infinity of eternity.

This transformation of the notion of eternity means that Paradise is not to be awaited in the future either, but arises in the present moment. Berdyaev says, "Paradise is not in the future, is not in time, but in eternity. Eternity is at- 
tained in the actual moment, it comes in the present" (Destiny 288). The peace of heaven and the nearness of God are actively sought out and experienced in the creative freedom and self-fidelity of the moment in existential time. Creative ethics manifests the Kingdom of God by breaking through time and enters into eternity (Destiny 288).

The Kingdom of God denotes not only redemption from sin and a return to original purity, but the creation of a new world. Every authentic creative act of man enters into it, every real act of liberation. It is not only the other world, it is this world transfigured. It is the liberation of nature from captivity.... And it begins now, at this moment. (Slavery 266)

The Kingdom of God is underfoot, enfolded in the depth of existential time, and to build it means to participate in the breakthrough of eternity into the order of time and history. However, we must be careful not to misunderstand this to mean that the Kingdom of God is, like political states, an order to be secured. Berdyaev's notion of the Kingdom revolts with the drive to realize its perfection against history that enslaves the moment-personality. If the Kingdom of God ever became a historical order, then woe to us who built it but will not witness its completion. And woe to those who succeeded its completion, for their freedom and their personality were unnecessary for this ultimate task. Berdyaev says, "The identification of the Church with the Kingdom of God, of the historical idea of the Church with the eschatological idea of the Kingdom of God, which derives from St. Augustine, is also one of the illusions born of objectified consciousness" (Slavery 266). Establishing and securing a utopia, even a spiritual order, are actions belonging to the enslaving order of time. The Kingdom of God is not secured, it is manifested in each and every present moment. As long as man is free, it is never completed, for its wholeness of God's reign is dependent on the depth of freedom provided by each and every personality.

Creative ethics is active eschatology, a full-fledged participation in apocalypse, the sundering of the orders of cosmic and historical time. The freedom of creative ethics is a manifestation of eternity, a manifestation of the peace and glory of the Kingdom of God. But He reigns here and now, and as personality for personality, we struggle so that each and every person in each and every moment may gain entry into the paradise we are all destined for. 


\section{Conclusion}

In the face of the moral chaos that confronts us in the present age, Nikolai Berdyaev exhorts us to be open to the new avenues and possibilities that reality opens for the self-realization of personality. With this openness, he asks us to be courageous, not to accept the world passively but to transform it into a moment of our self-realization. Through openness and courage, he calls us to creative ethics where we can create new forms of goodness as the concrete personalities that we are. This notion of ethics is founded on personality as the concrete actuality taken as a whole-in-itself, which transforms the world with its spirituality, and struggles to realize itself through its own self-transcending.

Creative ethics as a practice of personality reveals a unique Christian worldview. Good and evil are seen as correlative, axiological manifestations of the creative struggle of personality to realize itself. God is seen not as absolute but as intimately related to creation, as dynamic and self-transforming, as calling out to each person in the hope for a genuine co-creative response. Eternity is seen as something that is arrived at through the present moment seen as a whole unto itself, by the peace and self-fidelity of each creative act. And Paradise, the Kingdom of God, is built on each moment of self-fidelity.

It is hoped that through the thought of Nikolai Berdyaev one might come to look, even just for a moment, upon the heart of one's faith and spirituality, whatever one's religion may be. Perhaps one might find something creative and free that can be the ground of a struggle for true fidelity, which can be shared by all of us bearers of the spirit.

\section{Works Cited}

Berdyaev, Nikolai Alexandrovich. Christian Existentialism: A Berdyaev Anthology. Sel. and Trans. Donald A. Lowrie. London: George Allen \& Unwin, 1965.

---. The Destiny of Man. Trans. Natalie Duddington. New York: Harper \& Row, 1960.

---. The Meaning of History. New Brunswick: Transaction Publishers, 2006.

---. Slavery and Freedom. Trans. R.M. French. New York: Charles Scribner's Sons, 1944. Erlandson, Douglas K. "Timelessness, Immutability, and Eschatology." International Journal for Philosophy of Religion 9.3 (1978): 129-45. 
Garner, William R. and Edward B. Richards. "The Political Implications of Nicholas Berdyaev's Philosophy." Journal of the History of Ideas 31.1 (1970): 121-8.

Hartshorne, Charles. "Whitehead and Berdyaev: Is There Tragedy in God?" Journal of Religion 37.2 (1957): 71-84.

Hazelton, Roger. "Time, Eternity, and History." Journal of Religion 30.1 (1950): 1-12.

Lisin, Dimitri. "Philosopher of Freedom." 27 July $2009<$ http://vis-www.cs.umass. edu/ dima/mytexts/suff.html>

Richards, Edward B. "Nicholas Berdyaev: Christianity and History." Journal of Bible and Religion 28.4 (1960): 432-6.

\section{Works Consulted}

Copleston, Frederick. A History of Philosophy Vol. 10: Russian Philosophy. London: Continuum, 1986.

Seaver, George. Nicolas Berdyaev: An Introduction to His Thought. New York: Harper and Brothers, 1950. 